\title{
VACUUM CVD COATINGS TA ON TARGET W PLATE OF NEUTRONS SOURCE
}

\author{
B.V. Borts, I.M. Neklyudov, Yu.I. Polyakov, S.G. Rudenky, Yu.V. Lukirsky, \\ I.A. Vorobyov, A.A. Lopata \\ National Science Center “Kharkov Institute of Physics and Technology”, Kharkiv, Ukraine \\ E-mail: rudenkyi@kipt.kharkov.ua
}

The paper presents data on the creation of a tungsten target, protected from corrosion under irradiation with a power of up to $100 \mathrm{~kW}$. A protective coating of tantalum with a thickness of $250 \mu \mathrm{m}$ was deposited on the surface of tungsten plates $66 \times 66 \mathrm{~mm}$, thickness 10;6;4;3 mm. The coating has a solid-phase compound over the entire surface of tungsten and is hermetic. This was achieved by CVD (chemical vapor deposition) tantalum deposition in a vacuum of $2.66 \cdot 10^{-2} \mathrm{~Pa}$ on a plate surface heated to $\sim 1700 \mathrm{~K}$ using the thermal dissociation reaction of tantalum pentachloride vapor. Such tungsten plates, equipped with tantalum coatings with desired properties, were used in the Neutron Source installation of the NSC KIPT.

\section{INTRODUCTION}

The neutron-forming part of the target of the neutron source, based on the subcritical assembly, should consist of a set of tungsten plates hermetically packed in tantalum. Tantalum is used as a tungsten core sheath.
Coating tantalum on a tungsten core will have not only protective functions against tungsten corrosion, but also a plasticizing effect.

Neutron-forming plates must confirm the requirements given in Table.

\begin{tabular}{|l|c|c|}
\hline \multicolumn{1}{|c|}{$\begin{array}{c}\text { Geometrical dimensions } \\
\text { of the core: }\end{array}$} & Size, $\mathrm{mm}$ & Number, pieces \\
\hline in cross section & $66.0 \times 66.0-0.5-0.2$ & 7 \\
\hline \multirow{2}{*}{ plate thickness } & $10 \pm 0.15$ & 1 \\
\cline { 2 - 3 } & $6 \pm 0.15$ & 2 \\
\cline { 2 - 3 } & $4.0 \pm 0.1$ & 3 \\
\cline { 2 - 3 } & $3.0 \pm 0.1$ & - \\
\hline shell thickness & 0.25 & - \\
\hline $\begin{array}{l}\text { the size of the gap between the } \\
\text { plates for the flow of coolant }\end{array}$ & $1.75 \pm 0.05$ & \multicolumn{2}{|c|}{} \\
\hline
\end{tabular}

The body of the plates must have a solid-phase compound over the entire surface of the tungsten to ensure the transfer of thermal power to the refrigerant (water) from the incident beam with a power of $100 \mathrm{~kW}$ to the target and be airtight $[1,2]$.

The gap between the plates for the flow of the coolant is provided by the spacer tabs as shown in Fig. 1.

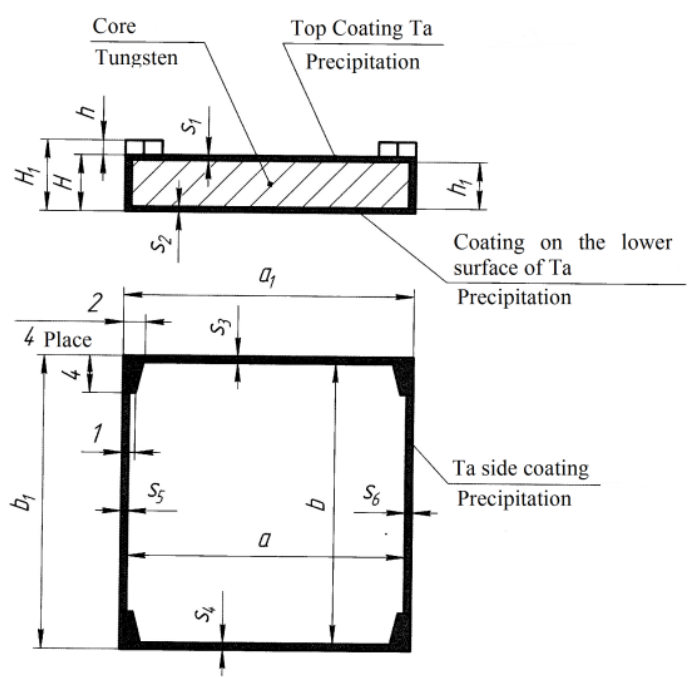

Fig. 1. Neutron-forming target plate with spacing protrusions
The formation of the coating, as well as distancing protrusions, is carried out by vacuum deposition of tantalum on a heated surface of a tungsten plate using the reaction of thermal dissociation of tantalum pentachloride vapor [3-5] .

\section{RESULTS AND DISCUSSION}

Test experiments on applying Ta to prototypes were performed on a vacuum unit with induction heating of the covered samples (Fig. 2).

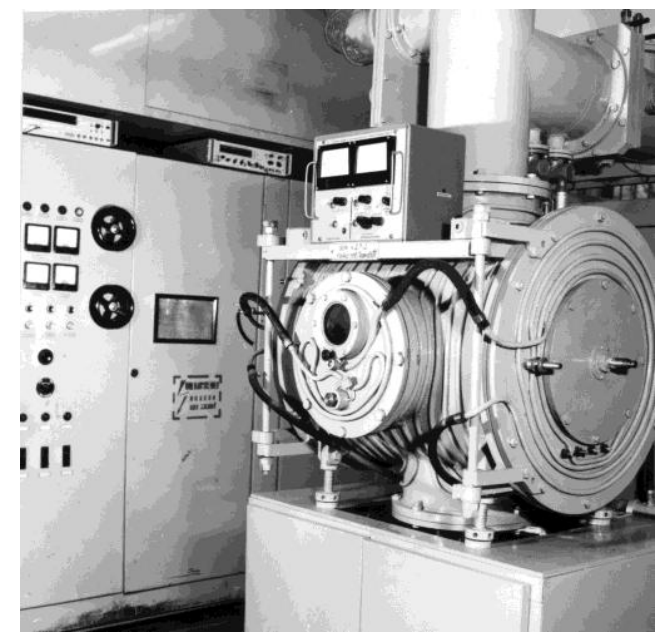

Fig. 2. Equipment for applying Ta-coatings 
The vacuum chamber was pumped out to $\sim 2.66 \cdot 10^{2} \mathrm{~Pa}$ using the NVBM-2.5 booster pump. Samples placed inside the inductor were heated to a predetermined temperature by adjusting the electromagnetic radiation power of the RFI-63-0.44 unit supplied to the inductor at a frequency of $440 \mathrm{kHz}$. For simulation tests in an aqueous medium (coolant) under the influence of a high-energy electron beam at one of the NSC KIPT accelerators, a test Ta coating was applied with a thickness of $240 . .250 \mu \mathrm{m}$ on the surface of a tungsten plate with a size of $48 \times 48 \times 4.7 \mathrm{~mm}$ (Fig. 3).

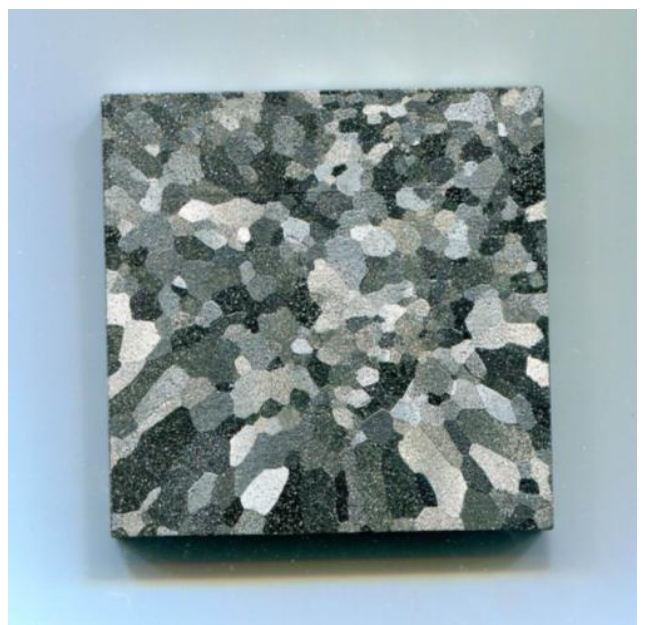

Fig. 3. Vacuum melted plate $W 48 \times 48 \times 4.7 \mathrm{~mm}$ with Ta coating $250 \mu \mathrm{m}$ thick. The grain structure of the substrate is developed in the coating due to epitaxial growth

To heat the plate in a vacuum chamber to a predetermined temperature, a replaceable cylindrical inductor with an inner diameter of $70 \mathrm{~mm}$ was made, made of a copper tube with a diameter of $10 \times 1 \mathrm{~mm}$, containing 6 turns. The resonance matching at a frequency of $440 \mathrm{kHz}$ of the inductor and the secondary winding of the RF transformer was achieved by connecting capacitor banks with a total capacity of up to $40.000 \mathrm{pF}$ to them. In this case, heating the sample to $1973 \mathrm{~K}$ was possible with the vibrational power of the RF installation of the ВЧИ- $63-0.44$ to $10 \mathrm{~kW}$. As a rule, the temperature in the peripheral part was several tens of degrees higher than in the center. The mouth of the $\mathrm{TaCl}_{5}$ steam line, $14 \mathrm{~mm}$ in diameter, was located at a distance of $50 \mathrm{~mm}$ from the surface of the sample placed in the central part of the inductor. The turns of the inductor were located at the minimum possible distance $(\sim 0.5 \mathrm{~mm})$ from each other, which made it possible to reduce the dispersion of $\mathrm{TaCl}_{5}$ vapors and thereby increase the utilization rate of $\mathrm{TaCl}_{5}$ (as well as the coating rate).

$\mathrm{TaCl}_{5}$ vapors from a container maintained at a temperature of $383 \mathrm{~K}$ were directed to the sample via a steam line made of a $10 \times 1 \mathrm{~mm}$ stainless steel tube and heated to $\sim 423 \mathrm{~K}$ by direct transmission of electric current. The end of the steam line was made of graphite in order to avoid chemical etching by the reagents involved in the deposition process and, accordingly, pollution of the Ta-coating with these reagents.
Unreacted $\mathrm{TaCl}_{5}$ vapors and reaction products were captured using a liquid nitrogen cooled trap.

Structurally, the trap is made in the form of a hollow, horizontally located stainless steel cylinder, equipped at the ends with shut-off valves KR-260 (developed by the NSC KIPT) plate-type. In the upper part of the cylinder shell, on a removable flange, there is a cylinder filled with liquid nitrogen, on the surface of which $\mathrm{TaCl}_{5}$ thermal dissociation reaction products (chlorine and unreacted chloride) condense.

On the side surface of the cylindrical shell of the trap there are holes for the inlet and subsequent drainage of an alkaline neutralizing solution. After the Ta deposition experiment, the internal volume of the trap is cut off from the installation vacuum system by the KR260 valves indicated above. Next, it becomes possible to neutralize the condensed chlorine and chloride by inlet of the corresponding alkaline solution and its subsequent discharge through the lower pipe of the trap. Finishing operation - disassembling and drying the internal surfaces of the trap.

With a deposition rate of $\leq 50 \mu \mathrm{m} / \mathrm{h}$ and utilization rates of $\mathrm{TaCl}_{5}$ of $25 . . .40 \%$ it is obtained coating about $250 \mu \mathrm{m}$ over the entire surface of the sample 48x48x4.7 mm.

An essential element of equipment for the implementation of the process is a removable evaporator of $\mathrm{TaCl}_{5}$ compound. It is made of X18H10T stainless steel and is a hollow cylinder equipped with an axial bellows-type valve from one of the ends, and an opening for the exhaust of $\mathrm{TaCl}_{5}$ vapor from the opposite end. The evaporator is charged with tantalum pentachloride in the form of a powder or pieces (preferably) in the absence of contact of $\mathrm{TaCl}_{5}$ with water vapor from atmospheric air (dry chamber). The indicated container is heated in a removable low-inertia furnace made in the form of a squirrel wheel with a heater made of nichrome wire wound around the wheel spokes. The set temperature of the container is maintained by means of a contact thermometer of the fuel dispenser type and an electronic key. The amount of tantalum pentachloride vaporized is determined by weighing the evaporator before and after the coating process.

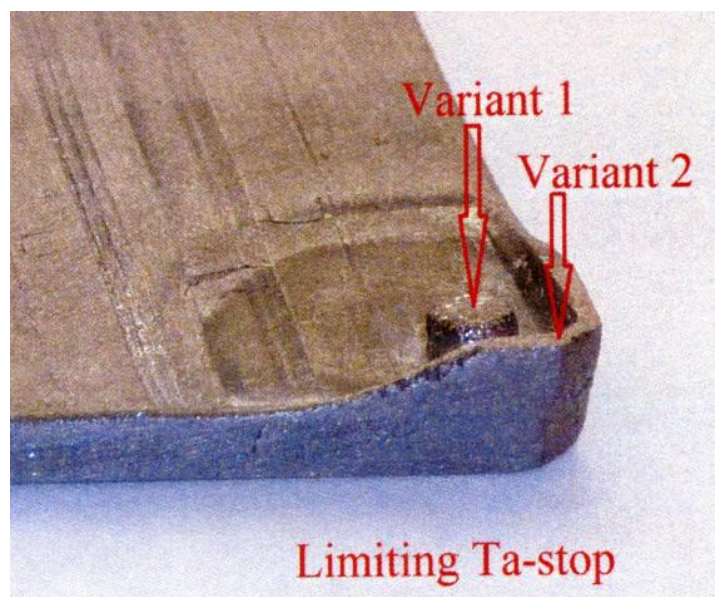

Fig. 4. Spacing protrusions of two types at one of the vertices of the target tungsten plate 
The formation of spacing protrusions done under the conditions of masking the surface of the product with a graphite plate, which prevents $\mathrm{TaCl}_{5}$ vapor from accessing the other surface of the tungsten plate, except for the open part intended for growing protrusions. (Fig. 4).

In this case, $\mathrm{TaCl}_{5}$ pairs are sent simultaneously from 4 nozzle openings, respectively, to each of the protrusions. The equalization of the mass flows of $\mathrm{TaCl}_{5}$ vapor arriving at each of their 4 protrusions is performed in a buffer chamber as a Knudsen effusion cell, the cavity dimensions of which significantly exceed the diameters of the nozzle openings for the exhaustion of $\mathrm{TaCl}_{5}$ vapor.

The primary analysis of the metallographic data of tantalum coatings obtained by chemical vapor deposition (CVD) was done on test samples of vacuum melted tungsten, tantalum tin, and also ARV graphite. Moreover, W, and Ta are materials of a neutron

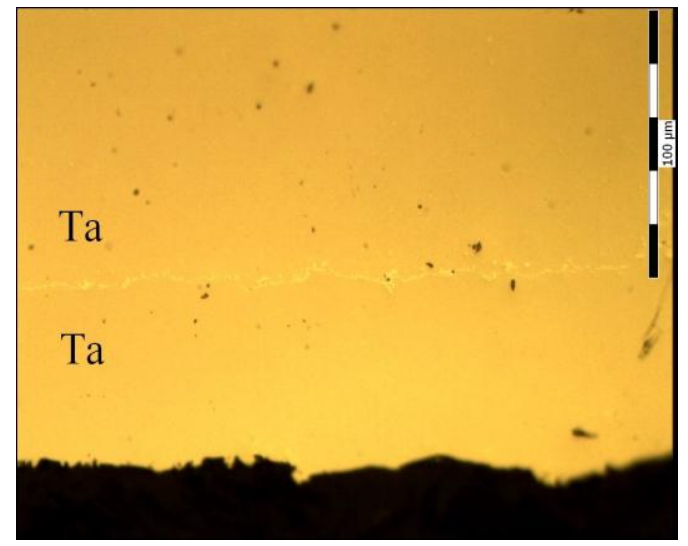

Fig. 5. Ta coating (bottom) on a Ta substrate. Coating temperature 1600; application time $90 \mathrm{~min}$; thickness $65 . .75 \mu \mathrm{m}$; microhardness of the substrate $2.04 \mathrm{GPa}$; coatings $-2.26 \mathrm{GPa}$

From the previously considered Ta coatings on Ta and $\mathrm{W}$, a thin intermediate layer of apparently $\mathrm{Ta}$ carbides is observed at the substrate - coating interface. Otherwise, these coatings are identical to the previous ones. From the data obtained it follows that the process

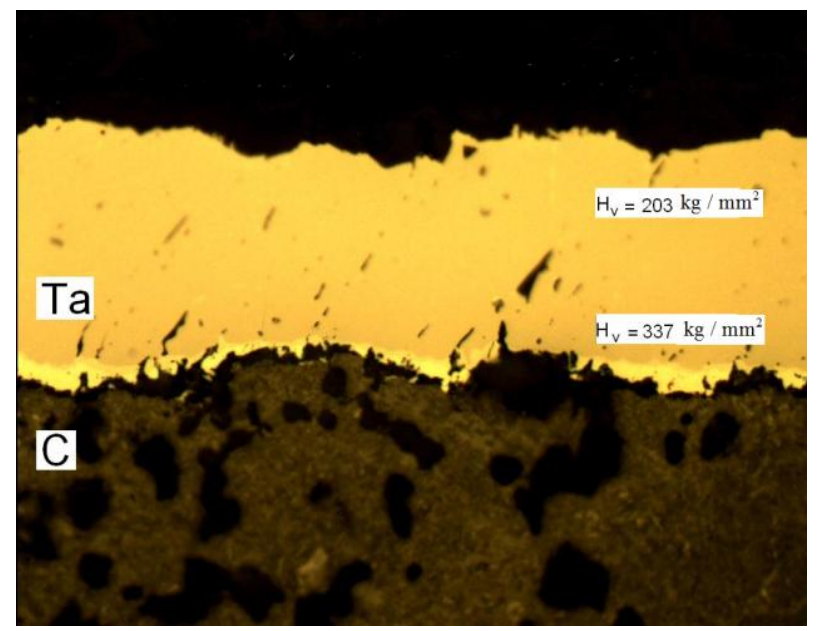

Fig. 7. Ta coating on ARV graphite. Application temperature - $1600 \mathrm{~K}$, application time $-90 \mathrm{~min}$, thickness $\sim 70 \mu \mathrm{m}$ generator target, and graphite is selected as an auxiliary model material for studying the process technology and its results, as well as a structural material in the manufacture of chemical reactor equipment.

The Ta coating on the Ta substrate (Fig. 5) has no visible defects, indicating the presence of through porosity, as well as delamination at the substrate-coating interface. The microhardness values of the substrate and coating practically do not differ.

Fig. 6 shows a microsection of a Ta coating on a tungsten substrate.

As in the case of a Ta coating on a Ta substrate, the absence of visible defects and delamination is observed. Note that the microroughnesses (depressions) of the surface of the $\mathrm{W}$ substrate are well filled with the coating material, which makes it possible to predict the operability of Ta coatings in the composition of the target being developed.

Ta coating on ARV graphite is shown in Fig. 7.

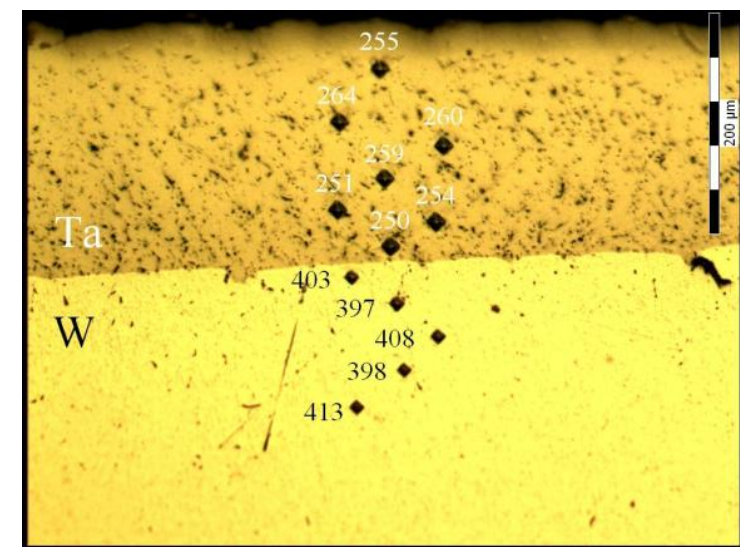

Fig. 6. Ta coating on a $W$-substrate.

Application temperature $1670 \mathrm{~K}$, time $120 \mathrm{~min}$, thickness $~ 200 \mu \mathrm{m}$

itself and the quality of the coating are practically independent of the selected substrate materials, which allows the use of graphite as a model material for testing and optimizing the technology.

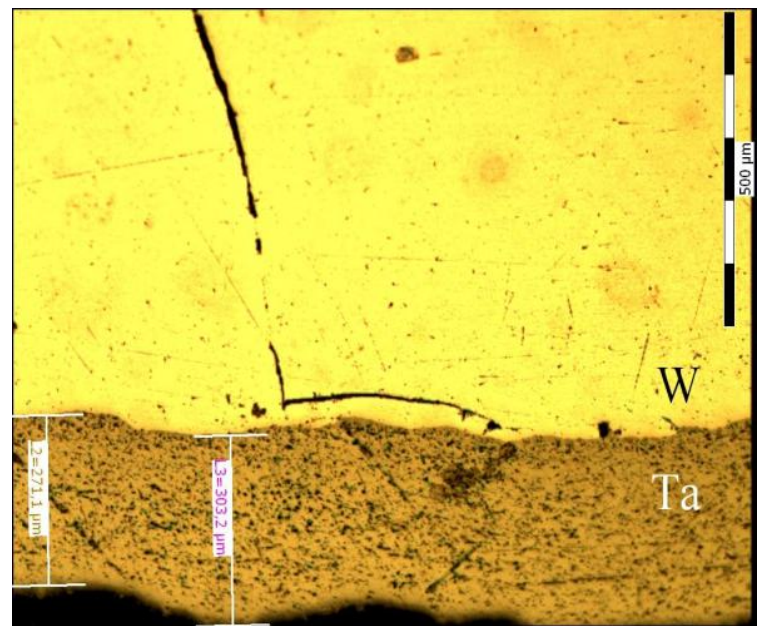

Fig. 8. Microsection of Ta coating on W(at kink). Detachment over the body of the $W$-substrate 
Note that the specific data obtained are consistent with established ideas about the adhesion and density of CVD coatings [5]. Their density is close to theoretical, and good adhesion occurs due to the chemical exchange interaction with the participation of chlorine and chlorides of various valencies developed at the early stages of coating growth. In this case, chlorides of the substrate material are formed, which enter the vacuum; in an opposite dense stream of the initial chloride, mixed with it, they return to the substrate and are already deposited together with the coating material (in this case, W with Ta, or a Ta substrate with Ta in the composition of the initial $\mathrm{TaCl}_{5}$ ). The result is good grip. Since $\mathrm{W}$ and Ta form a continuous series of solid solutions, in this case there are no obstacles to realizing good adhesion, which is observed in practice (Fig.8).

The fracture microsection photograph shows that when the sample is destroyed, the Ta coating is detached not along the W-Ta boundary, but along the body of the $\mathrm{W}$ or Ta coating, which illustrates the high adhesive ability of the tantalum CVD coating to the tungsten substrate.

\section{EVALUATION THROUGH POROSITY OF Ta-COATINGS}

The protection of $\mathrm{W}$-plates from contact with the refrigerant (water) by placing them in a Ta-coating shell is effective in the absence of through porosity in the coatings. To evaluate the protective anticorrosive properties of Ta coatings, the chemical technique widely used in the practice of creating protective coatings was applied, which consists in immersing samples of easily corroded material with a coating in an acid solution. In our case, these were molybdenum samples coated with tantalum, immersed in a solution of nitric acid $\left(\mathrm{HNO}_{3}\right)$ diluted with water in a ratio of $1: 1$. It is known that molybdenum dissolves rapidly, interacting with $\mathrm{HNO}_{3}$ at room temperature. It was of interest to experimentally establish the minimum (critical) thickness of the Ta coating capable of protecting Mo from dissolution in nitric acid.

For this, Mo samples with a diameter of $28 \mathrm{~mm}$ and a length of $50 \mathrm{~mm}$ were placed coaxially in the inductor of the vacuum chamber, heated to $1773 \mathrm{~K}$, and a stream of $\mathrm{TaCl}_{5}$ vapor was directed to their surface from the side of the end of these samples. The surface of the samples was not polished, i.e. she was substantially rough.

At the same time, at the end of the samples, the coating thickness was maximum (up to $100 \mu \mathrm{m}$ ), and on the cylindrical surface it decreased to a few microns, due to a decrease in the vapor density of $\mathrm{TaCl}_{5}$ near the indicated surface with distance from the end of the samples. The samples thus coated were immersed in nitric acid and operating for up to 7 days. As a result of observations, the absence of penetration of nitric acid to the base of Mo at tantalum thicknesses from $\sim 1$ to $100 \mu \mathrm{m}$ was established. To visually check the absence of through porosity, the Mo $\varnothing 28 \mathrm{~mm}$ sample was divided into two equal parts $25 \mathrm{~mm}$ long, after which a central part with a diameter of $26 \mathrm{~mm}$ was cut out in the part with a thinner coating. After dissolving the remaining part of the Mo base in $\mathrm{HNO}_{3}$, a particularly thin tube (several microns) of Ta was obtained (Fig. 9). When viewed through the gap, microholes (corresponding to through porosity) were not found.
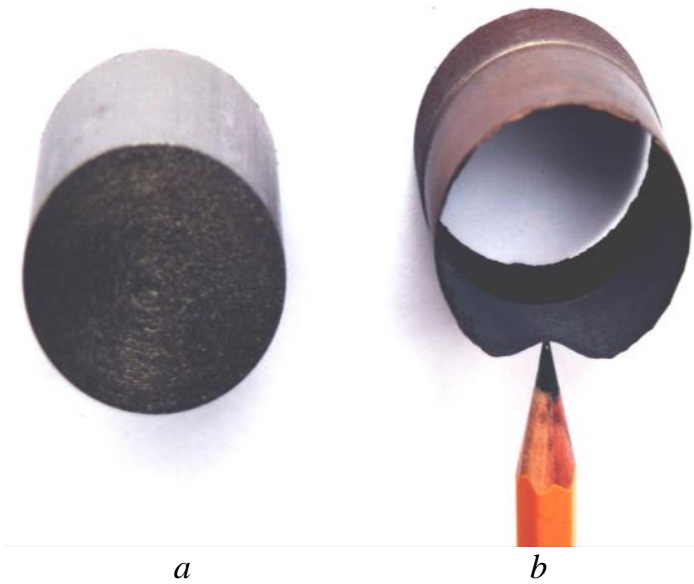

Fig. 9. Ta-coated Mo sample (a) and thin-walled tube made of Ta coating $(b)$ remaining after etching of the Mo base

To establish the critical thickness of the Ta coating, a disk with a diameter of $45 \mathrm{~mm}$ and a thickness of $0.5 \mathrm{~mm}$ was used, on which for $5 \mathrm{~min} .3 \mu \mathrm{m}$ thick was applied on the side of the supplied $\mathrm{TaCl}_{5}$ vapor stream. In this case, a coating with a thickness of tenths of a micron formed on the reverse side of the sample, which also prevented the action of $\mathrm{HNO}_{3}$ on the molybdenum of the substrate.

Thus, the estimated critical thickness of the protective anti-corrosion coating, in any case, does not exceed $1 \mu \mathrm{m}$.

\section{FEATURES OF IMPLEMENTATION OF CVD-APPLICATION PROCESS Ta-COATINGS FROM $\mathrm{TaCl}_{5}$ TO THE LATERAL SURFACE OF TUNGSTEN PLATES}

The formation of a localized tantalum pentachloride vapor stream directed perpendicularly to the side surface of a tungsten plate is performed using a collapsible multi-position nozzle device (Fig. 10).

The device contains a buffer chamber made of graphite in the form of a detachable hollow cylinder with a diameter of $140 \mathrm{~mm}$ and a height of $30 \mathrm{~mm}$, the top cover of which is equipped with an axisymmetric hole for connecting to the steam line from the tantalum pentachloride evaporator, and the bottom cover contains 16 diametrically opposite holes $\varnothing 10 \mathrm{~mm}$ (12 holes with a diameter of $100 \mathrm{~mm}$ and 4 holes $\varnothing 92 \mathrm{~mm}$ ). 4 holes on $\varnothing 92 \mathrm{~mm}$ are designed for the installation of steam conduits, providing the possibility of suspension of a tungsten plate. In this case, the vertices of the latter geometrically coincide with the axes of these tubes. The tops of the plate are installed in cuts at the ends of the tubes. The height of the cuts should correspond to the thickness of the particular plate selected for coating, and free washing of the surface of the plate near its top with tantalum pentachloride entering through the tubes should be ensured. Suspended in this way, the plate is subsequently mounted horizontally parallel to the plane of the inductor, made in the form of an Archimedes 
spiral and permanently placed inside the vacuum chamber. The distance between the inductor and the closest parts of the device is selected about $5 \mathrm{~mm}$ and depends on the RF power supplied to the inductor to heat the plate to a predetermined temperature.

The remaining 12 steam conducting tubes, 3 on each side of the square plate, contain cuts at the height of the middle of the thickness of the coated plate, which are designed to expire tantalum pentachloride vapors and form a uniform vapor flow across the square sides of the square plate. The threaded connection of the tubes to the cover of the buffer cylinder allows you to adjust the height of the cuts, depending on the specific thickness of the selected plate for coating.

During operation, the tantalum pentachloride vapor enters the buffer chamber, and due to the symmetry of the chamber, the vapor pressure is equalized by its volume, and, accordingly, the same value of the mass flow of tantalum pentachloride vapor flowing out from the cuts is ensured.
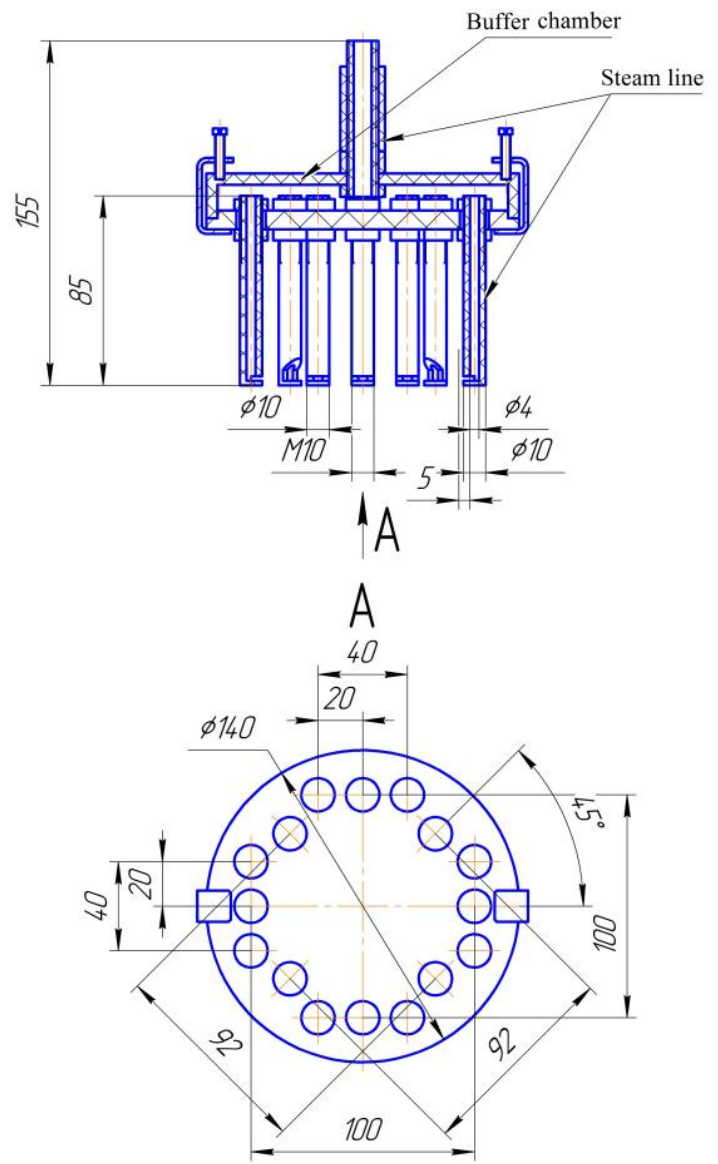

Fig. 10. Multiposition device for hanging a tungsten plate when coating $\mathrm{Ta}$

\section{CONCLUSIONS}

1. CVD coatings of tantalum were obtained and studied on samples of graphite, tantalum and tungsten. The data of these studies were used in the development of technological equipment for reactors for coating $\sim 250 \mu \mathrm{m}$ thick from tantalum on natural neutronforming tungsten plates, as well as the formation of spacing protrusions $\sim 1.75 \mathrm{~mm}$ high on them

2. It has been established that the tantalum layer thickness $\geq 1 \mu \mathrm{m}$ provides protection of molybdenum from corrosion, in particular in nitric acid, i.e. the coating is tight.

3. Technical capability is provided and tantalum coatings with specified characteristics are applied on laboratory equipment to an experimental batch of tungsten plates, and spacing protrusions of the required geometry are formed.

4. Natural tungsten plates equipped with tantalum coatings with desired properties were used in the Neutron Source installation at the NSC KIPT.

\section{REFERENCES}

1. Н.И. Айзацкий, Б.В. Борц, А.Н. Водин и др. Источник нейтронов ННЦ ХФТИ // Bonросы атомной науки и техники. Серия «Физика и техника эксперимента». 2012, №3, с. 3-17.

2. И.М. Неклюдов, И.М. Карнаухов, В.Н. Воеводин и др. Источник нейтронов, основанный на подкритической сборке, управляемой ускорителем электронов, - инструмент для материаловедческих исследований и производства медицинских изотопов. // Труды XX Международной конференции по физике радиационных явлений и радиациионому материаловедению, 10-15 сентября 2012 г., Алушта, c. $419-420$.

3. Ю.И. Поляков, Г.Н. Картмазов, Ю.В. Лукирский и др. Кинетика пиролиза летучих соединений металлов при нанесении покрытий в вакууме // Вопросы атомной науки и техники. Серия «Физика радиачионных повреждений $и$ радиационное материаловедение». 2011, №2, с. 163-167.

4. Ю.И. Поляков, С.Г. Руденький, Ю.В. Лукирский и др. Исследование процесса термической диссоциации пентахлорида тантала в вакууме // Вопросы атомной науки и техники. Серия «Физика радиачионных повреждений $u$ радиационное материаловедение». 2019, №2, с. 141-144.

5. Осаждение из газовой фазы / Под ред. К. Пауэлла, Дж. Оксли и Дж. Блочера мл. М.: «Атомиздат», 1970, 472 с.

Article received 11.09.2019

\section{ВАКУУМНЫЕ СVD-ПОКРЫТИЯ Та НА W-ПЛАСТИНАХ МИШЕНИ ИСТОЧНИКА НЕЙТРОНОВ}

\section{Б.В. Борц, И.М. Неклюдов, Ю.И. Поляков, С.Г. Руденький, Ю.В. Лукирский, И.А. Воробъев, А.А. Лопата}

Представлены материалы по созданию вольфрамовой мишени, защищенной от коррозии под облучением мощностью до 100 кВт. Защитное покрытие из тантала толщиной 250 мкм было нанесено на поверхность вольфрамовых пластин размером 66х66 мм, соответственно толщиной 10; 6; 4; 3 мм. Покрытие имеет 
твердофазное соединение по всей поверхности вольфрама и является герметичным. Указанное было достигнуто путем осаждения тантала методом CVD (химического осаждения из газовой фазы) в вакууме $2,66 \cdot 10^{-2}$ Па на нагретой до $\sim 1700 \mathrm{~K}$ поверхности пластины с использованием реакции термической диссоциации паров пентахлорида тантала. Такие пластины вольфрама, снабженные покрытиями тантала с заданными свойствами, использованы в установке «Источник нейтронов» ННЦ ХФТИ.

\section{ВАКУУМНІ СVD-ПОКРИТТЯ Та НА W-ПЛАСТИНАХ МІШЕНІ ДЖЕРЕЛА НЕЙТРОНІВ}

\section{Б.В. Бори, І.М. Неклюдов, Ю.І. Поляков, С.Г. Руденький, Ю.В. Лукирський, І.О. Воробйов, О.О. Лопата}

Представлені матеріали з створення вольфрамової мішені, захищеної від корозії під опроміненням потужністю до 100 кВт. Захисне покриття 3 танталу товщиною 250 мкм було нанесено на поверхню вольфрамових пластин розміром 66х66 мм, відповідно товщиною 10; 6; 4; 3 мм. Покриття має твердофазне з'єднання по всій поверхні вольфраму та є герметичним. Зазначене було досягнуто шляхом осадження танталу методом CVD (хімічне осадження з газової фази) у вакуумі $2,66 \cdot 10^{-2}$ Па на поверхні пластини, що нагріли до $\sim 1700$ К з використанням реакції термічної дисоціації парів пентахлориду танталу. Такі пластини вольфраму, забезпечені покриттями танталу із заданими властивостями, використані в установці «Джерело нейтронів» ННЦ ХФТІ. 